\title{
HEMOCHROMATOZĖS DIAGNOSTIKA IR AUTOPSIJOS REIKŠMĖ. KLINIKINIS ATVEJIS
}

\author{
Ieva Mažeikaitė1, Dalius Banionis', Sigitas Laima ${ }^{1,2}$, Algimantas Jasulaitis ${ }^{1}$ \\ ${ }^{1}$ Vilniaus universiteto Medicinos fakultetas, \\ ${ }^{2}$ Valstybine teismo medicinos tarnyba prie Lietuvos Respublikos sveikatos apsaugos ministerijos
}

Raktažodžiai: geležies perteklius, geležies kaupimo liga, staigi mirtis, autopsija.

\begin{abstract}
Santrauka
Hemochromatozè - bronzinè liga, kitaip dar vadinama geležies pertekliaus ar geležies kaupimo liga, kuriai būdingas organų (ypač kepenų, taip pat - kasos, širdies, sąnarių, kaulų, hipofizès, odos, nagų) pažeidimas dèl geležies pertekliaus organizme. Paveldima hemochromatozė yra viena dažniausių genetinių ligų tarp baltosios rasès žmonių. Šiaurès Europos populiacijoje nustatoma 1 iš 220-250. Pirminè hemochromatozè - tai autosominiu recesyviniu būdu paveldima liga, dažniausia susijusi su HFE genu. Pirminès hemochromatozès eiga iki vidutinio amžiaus (40-60 metų) asimptominè. Hemochromatozei būdinga triada: kepenų cirozé, cukrinis diabetas ir odos hiperpigmentacija. Kardiomiocitų pažeidimas sukelia širdies veiklos nepakankamumą ir gali būti staigios mirties priežastis. Dažniausiai liga diagnozuojama atsitiktinai - nustačius padidejjusią geležies koncentraciją kraujo serume ir pasireiškus sunkioms, kartais mirtinoms komplikacijoms. Sergant paveldima hemochromatoze nustatomas padidejęęs serumo feritinas bei transferino ịsotinimas. Paveldimą hemochromatozę diagnozuoti padeda genetinis ištyrimas - HFE geno C282Y, H63D mutacijų nustatymas. Pagrindinis hemochromatozès gydymo principas - sumažinti geležies toksinį poveikị. Pirminès hemochromatozès gydymo būdas yra flebotomija (kraujo nuleidimas). Pacientams, kuriems flebotomija yra kontraindikuotina arba jie netoleruoja šio gydymo metodo, taikomas medikamentinis gydymas - chelatais, kepenų transplantacija atliekama retai.
\end{abstract}

\section{İvadas}

Hemochromatoze - literatūroje kitaip dar vadinama ge- ležies pertekliaus (angl. iron overload) ar geležies kaupimo liga (angl. iron storage disease). Tai susirgimas, kuriam būdingas organų (ypač kepenų, taip pat - kasos, širdies, sąnarių, kaulų, hipofizès, odos, nagų) pažeidimas dèl geležies pertekliaus organizme. Klinikiniai ligos simptomai pasireiškia vèlai. Dažniausiai liga diagnozuojama atsitiktinai - nustačius padidejjusią geležies koncentraciją kraujo serume ir pasireiškus sunkioms, kartais mirtinoms komplikacijoms. Nors literatūroje akcentuojamas kepenų ir kasos pažeidimas, ne mažiau reikšmingas yra geležies pertekliaus sukeltas miokardo pakenkimas. Todèl ūmus širdies veiklos nepakankamumas gali būti staigios mirties priežastis. Svarbu laiku diagnozuoti geležies kaupimo ligą ir taikyti patogenezini gydymą. Esant dažnam ligos paplitimui, būtų tikslinga rutiniškai atlikti genetinius tyrimus kūdikiams nustatant hemochromatozę. Staigių mirčių atvejais, kai neišryškejję akivaizdūs vidaus organų pakitimai, histologinius preparatus reiktų dažyti Perlso reakcija (Perls prussian blue reaction) dèl galimo geležies kaupimo organuose.

Darbo tikslas: aptarti mokslinès literatūros duomenis apie hemochromatozès epidemiologiją, etiologiją, klinikinius simptomus, diagnostikos ir gydymo galimybes. Pristatyti klinikinį atvejị: paciento, kurị ištiko staigi mirtis, o galutinè diagnozè buvo nustatyta tik atlikus autopsini tyrimą.

\section{Tyrimo objektas ir metodai}

Parengiant straipsnị buvo apžvelgti PubMed, GeneReviews, Medline duomenų bazèse esantys straipsniai, kuriuose analizuojami hemochromatozès diagnostikos būdai ir problemos, pavèluoto diagnozavimo priežastys, pasekmès ir autopsinio tyrimo svarba rizikos grupių identifikavimui.

Epidemiologija. Paveldima hemochromatozè yra viena dažniausių genetinių ligų tarp baltosios rasės žmonių. Liga paplitusi visame pasaulyje, dažniausiai nustatoma šiaurès Europos populiacijoje - 1 iš 220-250 [1, 2].

Etiologija. Pirminè hemochromatoze - tai autosominiu recesyviniu būdu paveldima liga, dažniausiai su HFE genu 
susijusi hemochromatozè 1996 metais John Feder su bendraautoriais paskelbè, kad pacientams, kuriems hemochromatozè pasireiškė fenotipiškai, buvo nustatytos HFE geno (lokalizuotas 6 chromosomos trumpajame petyje) C282Y ir H63D mutacijos, ypač kilusiems iš šiaurès Europos [3, 4]. $80 \%$ pacientų, sergančių paveldima hemochromatoze, nustatoma C282Y mutacija. Dalis pacientu heterozigotinès formos su C282Y ir H63D mutacijomis. Reikšmingos mutacijos kituose geležies metabolizmą nulemiančiuose genuose, kurie koduoja: hemojuveliną (HJV), hepcidiną (HAMP), transferino receptorių 2 (TFR2), feroportiną (SLC40A1) $[4,5]$.

Antrinès hemochromatozès priežastys: geležies nepanaudojimas ir kaupimasis, kai slopinama eritropoezė; geležies perteklius dẻl didelio suirusių nepilnaverčių eritrocity kiekio - nesavalaikè hemolizė bei yrant eritrocitams po transfuzijos. Antrinei hemochromatozei svarbios igimtos ir igytos priežastys, kurių metu vyksta minèti procesai (1 lentelè) $[6,7]$.

Klinikiniai simptomai. Pirminès hemochromatozès eiga iki vidutinio amžiaus (40-60 metų) asimptominè [8]. Klinikiniai simptomai pasireiškia vèlyvose ligos stadijose, kai sutrinka organų funkcijos, o histologinio tyrimo metu audiniuose randama gausi hemosiderino depozicija. Hemochromatozei būdinga triada: kepenų cirozè, cukrinis diabetas ir odos hiperpigmentacija [7].

Kepenų pažeidimas. Geležis akumuliuojasi kepenų ląstelèse, vystosi hepatomegalija, kepenų fibrozė ir cirozè. Dažniausia geležies kaupimo ligos išraiška yra mikronodulinè kepenų cirozè, asocijuota su cukriniu diabetu. Pirminè hemochromatozè gali komplikuotis hepatoceliuline karcinoma (HCC), kartu nustatoma ir cirozè. Literatūroje aprašomi atvejai, kai pacientams HCC išsivysto be kepenu cirozès. Pastebèta, kad cholangiokarcinomos atvejų dažnis didèja $[6,9]$. 45\% pacientų, sergančių paveldima hemochromatoze, miršta dèl HCC [10].

1 lentelè. Antrinès hemochromatozès priežastys

\begin{tabular}{|l|l|}
\hline \multicolumn{1}{|c|}{ Igimtos } & \multicolumn{1}{c|}{ Igytos } \\
\hline Talasemija & Dažnos transfuzijos \\
Pjautuvo formos ląstelių & Mielodisplazinis sindromas \\
anemija & Lėtinės kepenų ligos (alkoho- \\
Sideroblastinė anemija & linė kepenų cirozė, steatohe- \\
Paveldima sferocitozė & patitas) \\
Igimta diseritropoetinė & Dažnos hemodializės \\
anemija & Po portokavalinio šuntavimo \\
Vėlyvoji odos porfirija & procedūros \\
Piruvato kinazės deficitas & Geležies preparatų ar papildų \\
Diamond-Blackfan anemija & perdozavimas \\
& Geležies perteklius maiste \\
\hline
\end{tabular}

Cukrinis diabetas. Geležies perteklius yra cukrinio diabeto išsivystymo rizikos veiksnys. Naujausi tyrimai rodo, kad sergantiems paveldima hemochromatoze cukrinis diabetas nustatotomas $13-22 \%$, o sutrikusi gliukozès tolerancija - 18-30\%. Geležis, kuri kraujo plazmoje yra nesusijungusi su pernešančiu baltymu transferinu, sukelia oksidacini stresą. Šis mechanizmas sukelia ląstelių, tarp jų kasos $\beta$ ląstelių, pažeidimą. Hemochromatozès sukelto cukrinio diabeto gydymui būtinas insulinas [11].

Širdies pažeidimas. Hemochromatozei būdingas širdies pažeidimas. Kardiomiocituose geležis atpalaiduojama kaip hemosiderinas ar laisva forma. Susidaro aktyvuotas $\mathrm{O}_{2}$ ir reaktyvūs tarpiniai $\mathrm{O}_{2}$ produktai, kurie inicijuoja lipidu peroksidaciją, membranos pralaidumo pokyčius - įvyksta kardiomiocitų nekrozė $[12,13]$.

Sergant antrine hemochromatoze kardiomiopatija pasireiškia dažniau nei pirminè. Nustatyti du širdies pažeidimo fenotipai. Pirmasis tipas - dilatacinè kardiomiopatija, kuriai būdinga kairiojo skilvelio remodeliacija su kameros išsiplètimu ir sienelès raumens išplonejjimu. Sutrikusi sistolinè funkcija sąlygoja nepakankamą minutinį širdies tūrị organizmo metaboliniams poreikiams užtikrinti. Antrasis tipas - restrikcinè kardiomiopatija, pasireiškia kairiojo skilvelio diastoline disfunkcija (ribojamas skilvelio prisipildymas), kraujo tūris išmetamas sistolès metu yra normalus, tačiau vystosi plautinè hipertenzija, galiausiai invyksta dešiniojo skilvelio dilatacija [7]. Skilvelių pažeidimas sukelia širdies veiklos nepakankamumą ir staigią mirti. Supraventrikulinès aritmijos ar atrioventrikulinè blokada pasireiškia dèl laidžiosios sistemos pažeidimo [7, 12]. Geležies pertekliaus sukelta kardiomiopatija yra grižtamas procesas, tik tais atvejais, kai liga diagnozuojama anksti ir skiriamas agresyvus gydymas chelatais [14].

Hipogonadizmas, impotencija, amenorejja. Geležies depozitai hipofizejje sukelia pogumburio - hipofizès - gonadu ašies pakenkimą. Išsivysto hipogonadizmas, impotencija, amenorèja. Vyrams, kuriems pasireiškia izoliuotas hipogonadotropinis hipogonadizmas, reikia itarti hemochromatozę. Jeigu hipogonadizmas diagnozuojamas ankstyvoje stadijoje, gali regresuoti. Androgenų terapijos taikymas padidina hepatoceliulinès karcinomos riziką [11].

Artropatija, artralgijos. Sergant paveldima hemochromatoze pasireiškia artropatija - progresuojantis poliartritas. Pirmiausia pažeidžiami antras ir trečias metakarpofalanginiai (MKF) sąnariai. Priežastis, dẻl kurios pažeidžiami MKF sąnariai, nežinoma. Gali būti pakenkti stambieji sąnariai (klubo, kelio, čiurnos, peties, alkūnès). 30\% pacientų liga manifestuoja sąnarių pažeidimo simptomais. Pacientams, vyresniems nei 50 metų, artropatija dažniausiai nustatoma jau diagnozavus hemochromatozę. Artropatijos 
dažnis svyruoja nuo 24\% iki 81\%. Faktoriai, susiję su pasireiškimu: amžius, serumo feritino koncentracija $>1000$ $\mu \mathrm{g} / \mathrm{mL}$ ir C282Y homozigotiškumas. Dažniausi simptomai yra sąnarių sustingimas, skausmingi judesiai ir nežymus sąnarių patinimas. Klasikiniu atveju uždegiminis procesas sąnariuose minimalus, tačiau uždegiminiai simptomai gali kisti. Jie ypač ryškūs sergant kalcio pirofosfatų dihidratų kristalų susikaupimo liga (pirofosfatine artropatija). Hemochromatoze yra antrinès pirofosfatinès artropatijos priežastis $[15,16]$.

Osteoporozè. 25 - 50\% pacientų nustatoma osteoporozè. Dažniausiai osteoporozè pasireiškia dèl hemochromatozès sukelto kitų organų pažeidimo, pavyzdžiui, hipogonadizmo, pažengusios kepenų ligos [16].

Odos hiperpigmentacija. Alopecija. Koilonichija. Odos hiperpigmentacija yra velyvas ligos simptomas. $90 \%$ pacientų paveldimos hemochromatozès diagnozès nustatymo metu aptinkama odos pigmentacija. Odos pigmentacija dažniausiai yra generalizuota. Kartais pigmentacija ryškesnè nuo saulès neapsaugotose vietose - veide, tiesiamuosiuose dilbių, plaštakų dorzaliniuose paviršiuose, blauzdose ir kelių srityje [17]. Paciento oda būna: bronzinès spalvos (atsiranda dèl baziniame sluoksnyje padidejusios melanino depozicijos); pilkos spalvos (dèl geležies kaupimosi) [17, 18]. 15-20\% pacientų stebima gleivinių pigmentacija [17]. Nustatyta, kad yra koreliacija tarp epidermyje esančios geležies koncentracijos ir kepenyse esančių sankaupų [19]. Koilonichija nustatoma $50 \%$ sergančiujų hemochromatoze, lokalizuota ichtiozė pasitaiko 40\%, kai kuriems pacientams atsiranda alopecija, odos atrofija $[17,18]$.

\section{Diagnostika}

Laboratorinè diagnostika. Dažnai liga diagnozuojama atsitiktinai - profilaktinio patikrinimo metu, kai aptinkama padidejusi geležies koncentracija kraujo serume. Sergant paveldima hemochromatoze nustatomas padidejęs serumo feritinas bei transferino issotinimas (TS) (moterims paprastai $>50 \%$, vyrams $>60 \%$ ). Šie rodikliai rodo padidejusias geležies atsargas organizme. Serologiniai geležies žymenys (TS, feritinas) paprasti ir informatyvūs tyrimai, kai dar nèra ryškios klinikinès simptomatikos bei kepenų cirozės $[1,4,5]$.

Genetinis ištyrimas. Paveldimos hemochromatozès diagnozę patvirtina HFE geno C282Y, H63D mutacijų nustatymas $[1,2,4,5,9]$. Genetinį tyrimą rekomenduojama atlikti, jei TS $\geq 45 \%$ arba serumo feritino lygis (vyrams $>300$ $\mathrm{ng} / \mathrm{mL}$, moterims $>200 \mathrm{ng} / \mathrm{mL}$ ). The American Association for the Study of Liver Diseases rekomenduoja atrankinę patikrą (laboratoriniai ir genetiniai tyrimai) pacientams, kurių pirmos eilès giminaičiai sirgo paveldima hemochromatoze asocijuota su HFE genu, ir taip užtikrinti ankstyvą ligos diagnostiką ir komplikacijų prevenciją [1].

Instrumentiniai tyrimai. Atliekamas krūtinès ląstos rentgenologinis tyrimas. Kompiuterine tomografija (KT) ir magnetiniu branduoliu rezonanso tyrimas (MRT) naudingi stebèti ligos dinamiką. MRT tyrimas informatyvus vertinant širdies pažeidimą [14].

Kepenų biopsija. Sergant paveldima hemochromatoze rekomenduojama atlikti kepenų biopsiją, jeigu kepenų fermentai (ALT, AST) yra padideję arba feritino koncentracija $>1000 \mu \mathrm{g} / \mathrm{L}$. Pacientams, kurie nèra $\mathrm{C} 282 \mathrm{Y}$ homozigotinès ar heterozigotinès formos, bet turi geležies kaupimo fenotipinių požymių, taip pat rekomenduojama biopsija ligai diagnozuoti ir numatyti prognozę $[1,4]$.

Autopsija. Autopsija svarbi nustatant hemochromatozę mirusiems, kai liga nebuvo diagnozuota asmeniui esant gyvam. Diagnozuojant hemochromatozę autopsijos metu, svarbiausias tyrimas yra histologinis, kai organu preparatai dažomi Perlso reakcija (Perls prussian blue reaction). Autopsijos metu diagnozuota hemochromatozè, kuri paveldima genetiškai, gali apsaugoti mirusiojo pirmos eilès artimuosius diagnozuojant ir gydant šią ligą. Svarbu atlikti autopsiją staigios mirties atvejais, kai nèra akivaizdžių sužalojimų, patologinių vidaus organų pokyčių, o anamnezės duomenys apie mirusiojo sveikatą iki mirties yra minimalūs.

Gydymas. Flebotomija. Pagrindinis hemochromatozès gydymo principas - sumažinti geležies toksini poveikị. Pirminès hemochromatozès gydymo būdas yra flebotomija - kraujo nuleidimas. Flebotomijos efektyvumą parodo: sumažèjusi odos hiperpigmentacija, nuovargis bei kepenų fibrozès laipsnis, nustatomas atlikus kepenų biopsiją [4, 20]. Kraujo nuleidimas neveiksmingas gydant MKF artropatiją, hipogonadizmą, diabetą ir kepenų cirozę $[1,2,4]$. Flebotomijos metu pašalinama $500 \mathrm{ml}$ kraujo kas savaitę, kol hemoglobino koncentracija tampa 120 - $130 \mathrm{~g} / \mathrm{L}$. Geležies atsargų išeikvojimas laikomas efektyviu, jeigu serumo feritino koncentracija $\leq 50 \mathrm{ng} / \mathrm{mL}$ ir serumo transferino ịsotinimas $<50 \%$. Pacientams taikomos $4-8$ flebotomijos per metus siekiant išlaikyti serumo feritino koncentraciją $\leq 50$ $\mathrm{ng} / \mathrm{mL}[1,2,4,18]$.

Chelatu terapija. Pacientams, kuriems flebotomija yra kontraindikuotina arba jie netoleruoja šio gydymo metodo, taikomas medikamentinis gydymas - chelatais. Šie preparatai pašalina nesurištą su transferinu geležį iš kraujo plazmos ir ląsteliu - organizmas apsaugomas nuo žalingo laisvos geležies poveikio. Naudojami vaistiniai preparatai: deferaziroksas, deferipronas, deferoksaminas [1, 4].

Chirurginis gydymas. Ortotopinè kepenų transplantacija atliekama, kai nustatoma galutinès stadijos kepenų liga. 
Be to, transplantacija gali būti gydymo būdas pacientams, kuriems yra dekompensuota cirozė ar HCC. Pacientų, sergančių hemochromatoze, pooperacinès baigtys yra blogos dèl infekcijų, ypač pirmaisiais metais po chirurginès intervencijos bei kardiomiopatijos [2, 4].

\section{Klinikinis atvejis}

53 metų vyras buvo hospitalizuotas i ligoninès reanimacijos ir intensyviosios terapijos skyrių dèl tris paras
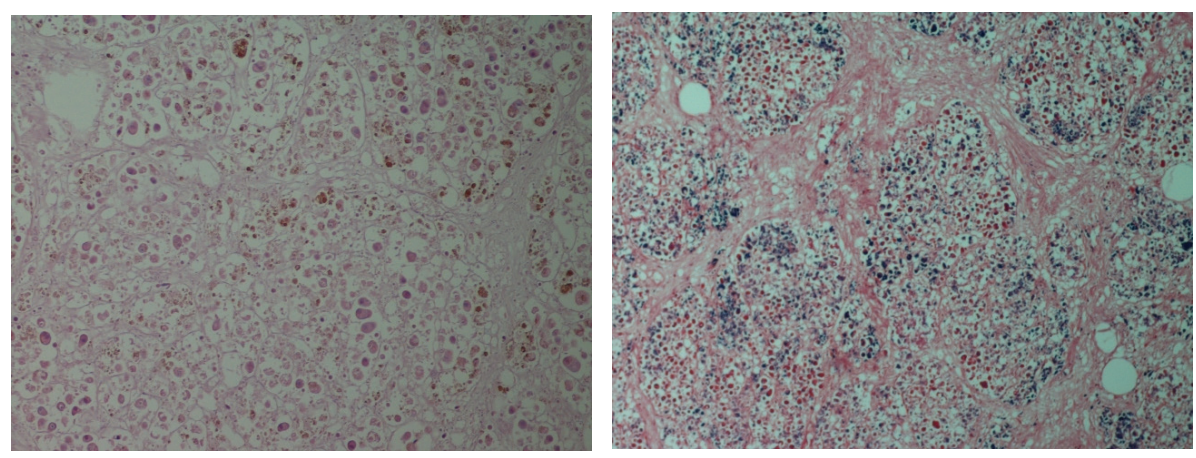

1 pav. Kasos acinusų dažymas hematoksilinu 2 pav. Kasos dažymas Perlso reakcija - eozinu

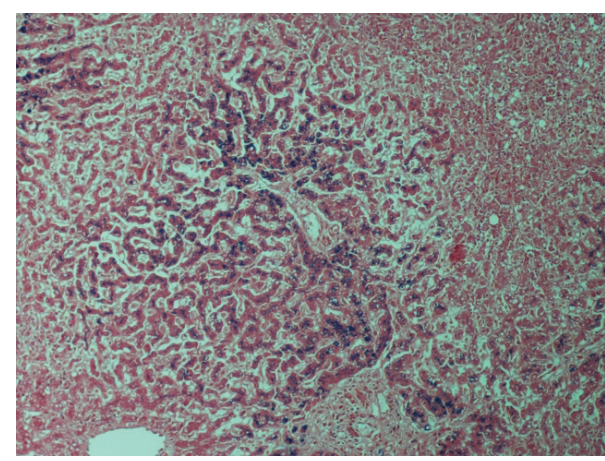

3 pav. Perlso reakcija - kepenys
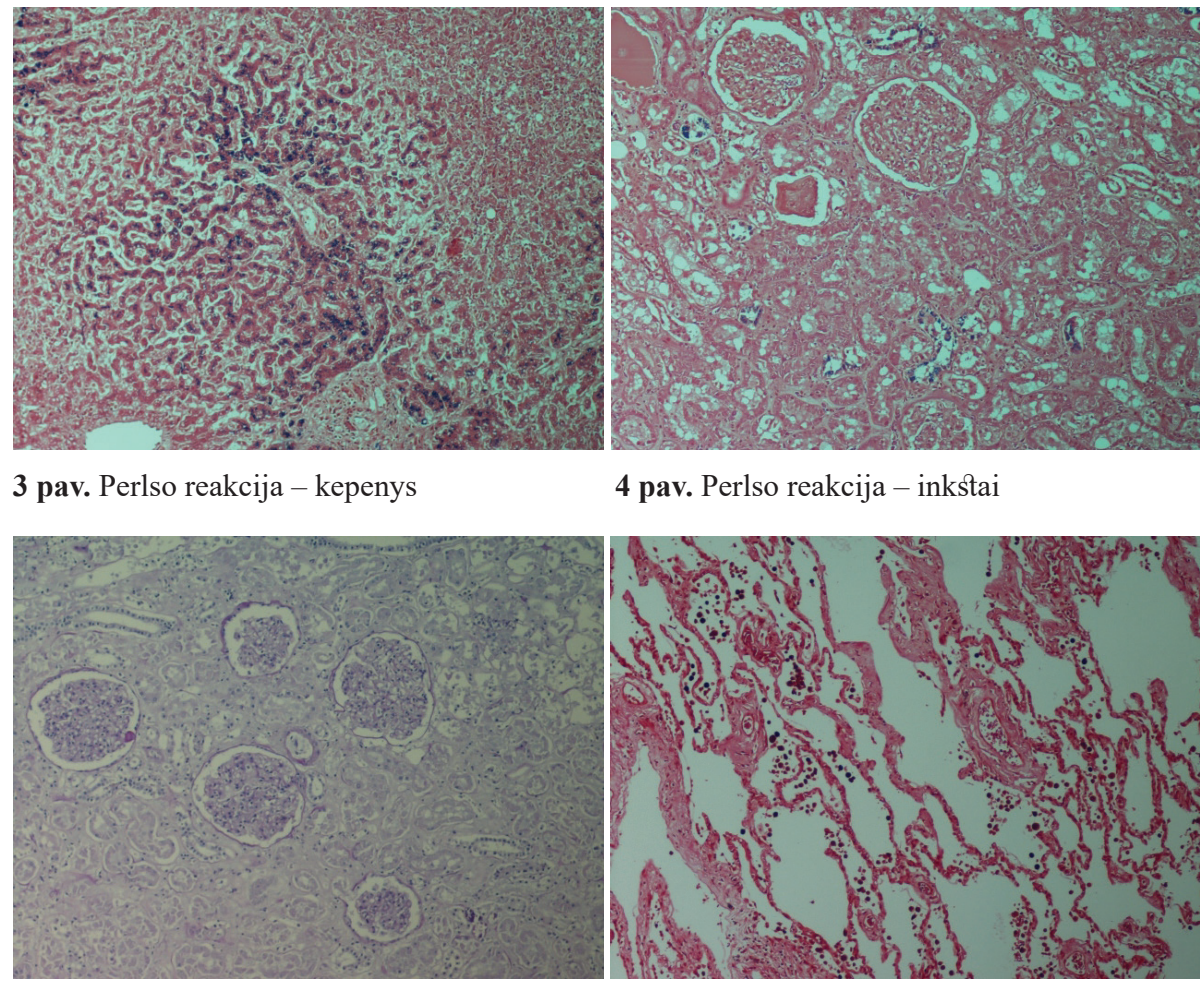

5 pav. Inkstai. Dažyta PAS (panaudojant periodinę rūgšties ir Šifo reagento reakciją) metodu trunkančio intensyvaus pilvo skausmo ir vieno epizodo vèmimo juodu krauju.

Paciento bendra būklè labai sunki, dekompensuota. Arterinis kraujo spaudimas (AKS) 70/40 mmHg, širdies susitraukimų dažnis (ŠSD) 172 k./min., stebima ryški vazokonstrikcija, cianozè. Pilvas palpuojant skausmingas pagal vizualinę analogijos skalę (VAS) 8 balai, raumenys įtempti.

Laboratoriniu tyrimų rezultatai nustate: leukocitozę (leukocitu skaičius - 16,3 x 109/L), lengvo laipsnio anemiją (hemoglobino koncentracija - $119 \mathrm{~g} / \mathrm{L}$ ), ūmini inkstų funkcijos nepakankamumą (šlapalo koncentracija - 13,7 mmol/L, kreatinino koncentracija - 136 $\mu \mathrm{mol} / \mathrm{L})$, elektrolitų disbalansą - hiperkalemiją $(5,8 \mathrm{mmol} / \mathrm{L})$, hiponatremiją $(134 \mathrm{mmol} / \mathrm{L})$, hipochloremiją $(95,4 \mathrm{mmol} / \mathrm{l})$, ūmini kepenų funkcijos nepakankamumą (aspartataminotransferaze (AST) - $717 \mathrm{U} / \mathrm{L}$, alaninaminotransferazė (ALT) - $1351 \mathrm{U} / \mathrm{L}$ ), hemolizę (bendroji bilirubino koncentracija - 171 $\mu \mathrm{mol} / \mathrm{L}$, tiesioginio bilirubino koncentracija $-37,4 \mu \mathrm{mol} / \mathrm{L}$ ), hipokoaguliaciją (aktyvintas dalinis tromboplastino laikas (APTT) - $46 \mathrm{~s}$, protrombino komplekso aktyvumas (SPA) $17 \%$, tarptautinis normalizuotas santykis (INR) - 2,96). Kraujyje rasta $0,1 \%$ etilo alkoholio. Taip pat metabolinę (laktatinę) acidozę ( $\mathrm{pH}-6,975$, anglies dioksido parcialinis slègis (pCO2) - 36,4 $\mathrm{mmHg}$, deguonies parcialinis slègis $\left(\mathrm{pO}_{2}\right)-21,5 \mathrm{mmHg}$, laktatai $-15 \mathrm{mmol} / \mathrm{L})$. Diagnozé: nepatikslintų medžiagų toksinis poveikis, dauginis organų funkcijos sutrikimas.

Tolimesnis ligos progresavimas buvo žaibiškas. Pacientas intubuojamas, pradedama dirbtinè plaučiu ventiliacija (DPV). Pilvas skausmingas, žarnu peristaltika neišklausoma. Illeistas nazogastrinis zondas - gautas skaidrus skystis su nedideliu 
kiekiu hematino (apie $300 \mathrm{ml}$ ). Išryškèjo bradikardija. Pacientas gaivinamas (skirti medikamentai: adrenalinas, amiodoronas, atropinas, natrio bikarbonato tirpalas, noradrenalinas). Širdies veikla atsistatè. Stebima anurija. Pakartoti laboratoriniai tyrimai nustatė: progresuojančią hipokoaguliacinę būklę (APTT - $216 \mathrm{~s}$; SPA $<6 \%$; INR <6,3; fibrinogenas $-0,3 \mathrm{~g} / \mathrm{L}$ ), kartu padideję D-dimerai - 200 $000 \mu \mathrm{g} / \mathrm{L}$, tokie rodikliai gali rodyti krešèjimo faktorių išeikvojimą ir tebevykstančią diseminuotą intravaskulinę koaguliaciją. Paciento hemodinamika nestabili (AKS - 70/30 $\mathrm{mmHg}$ ). Progresuoja inkstų funkcijos nepakankamumas (šlapalo koncentracija - $12 \mathrm{mmol} / \mathrm{L}$, kreatinino koncentracija $-194 \mu \mathrm{mol} / \mathrm{L}$ ). Išsekus organizmo gyvybiniams rezervams - konstatuojama mirtis.

Dèl staigios (nuo hospitalizacijos nepraèjus 24 valandoms) ir neaiškios mirties priežasties atlikta autopsija, kurios metu buvo aptikti netikèti radiniai. Kasa izoliuotai išoriškai ir pjūvyje pilkšvai juodos spalvos, be aplinkinių audinių reakcijos. Širdis 495 g svorio, kairiojo skilvelio svoris 140 g, dešiniojo - 90 g. Šrdies vožtuvų apimties bei traktų rodikliai - parodè dilatacinę hipertrofinę kardiomiopatiją. Histologiškai vidaus organuose stebimi hemosiderino depozitai. Kasoje stebima: židininè fibrozè, lipidozè, hemosiderinas acinozinų ląstelių citoplazmoje (1-2 pav.). Širdies netolygi pilnakraujystè, smulkiažidininè perivaskulinè miokardo fibrozè, hemosiderinas kardiomiocituose. Histologiškai - kepenyse stazinè pilnakraujystė, smulkiavakuolè hepatocitų lipidozè, hemosiderinas hepatocituose (3 pav.), smulkiažidininè hepatocitų nekrozè. Suformuluota diagnozė: pagrindinè liga - nenustatytos pirminès kilmès hemochromatoze, remiantis autopsijos metu rasta juoda kasa, histologinio tyrimo duomenimis (hemosiderino depozicija hepatocituose, kardiomiocituose, kasos acinoziniu ląstelių, inkstų kanalèlių epitelio (4-5 pav.) ir antinksčių ląstelių citoplazmoje). Pagrindinès ligos komplikacijos - dilatacinè hipertrofinè kardiomiopatija, metabolinè acidozè, prieširdžių virpėjimas, širdies funkcijos nepakankamumas, ūmus širdies ir kvėpavimo veiklos sutrikimas. Gretutinès ligos - širdies vainikinių arterijų aterosklerozès III stadija, kepenų suriebejjimas, galvos smegenų minkštujjų dangalų fibrozè.

\section{Diskusija}

Sergant hemochromatoze geležis kaupiasi vidaus organuose, todèl klinikinè ligos išraiška gali būti įvairialype (pasireiškia - kardiomiopatija, artritu, odos hiperpigmentacija, nevaisingumu ir kt.), kai simptomai išryškèja tik vèlyvose ligos stadijose. Būtent todèl ši patologija dažnai lieka neįtarta, kai ištinka staigi mirtis.

Hospitalizacijos metu pacientas buvo detaliai ištirtas, atlikta daug tyrimų, tačiau liga nebuvo diagnozuota. Visgi svarbu atkreipti dèmesi, jog nebuvo atlikti rutininiai tyrimai, tokie kaip - geležies koncentracijos nustatymas kraujo serume, transferino įsotinimo bei serumo feritino tyrimai, kurie būtų leidę įtarti hemochromatozę. Tik autopsinio tyrimo rezultatai atskleide staigios mirties priežastį. Pilkšvai juoda kasos spalva padejo ịtarti geležies kaupimo ligą. Atlikti histologiniai tyrimai naudojant specialų dažymo metodą patvirtino diagnozę. Vis dèlto diferencijuoti, ar tai buvo pirmine, ar antrinè hemochromatozè, sudètinga. Galutinai pirminès hemochromatozès diagnozę patvirtina tik genetiniai tyrimai $[4,5]$.

Autopsinis tyrimas leidžia išaiškinti iki mirties nediagnozuotos hemochromatozès atvejus, taip nustatomi ir taikant prevencines priemones apsaugomi pirmos eilès giminès. Mirtinų hemochromatozès sukeliamų baigčių išvengti padeda periodiškai atliekamos flebotomijos - nuleidžiant kraują [21].

\section{Išvados}

Kadangi hemochromatozès klinikiniai simptomai ilgai nepasireiškia, todèl liga dažnai diagnozuojama pavèluotai. Dèl medicinos mokslo pažangos ir spartaus technologijų vystymosi hemochromatoze diagnozuojama dažniau ir ankstyvose ligos stadijose. Reikia detaliai ištirti pacientus, kuriems pasireiškia akivaizdūs kepenų pažeidimo požymiai - hemochromatozès diagnozei eksliuduoti. Autopsijos metu mirusiajam pirmą kartą nustačius hemohromatozès diagnozę, turi būti genetiškai tiriami mirusiojo pirmos eilès giminaičiai siekiant diagnozuoti hemochromatozę ir laiku suteikti gydymą.

\section{Literatūra}

1. Bacon BR, Adams PC, Kowdley KV, Powell LW, Tavill AS; American Association for the Study of Liver Diseases. Diagnosis and management of hemochromatosis: 2011 practice guideline by the American Association for the Study of Liver Diseases. Hepatology 2011 Jul; 54(1): 328-43.

http://dx.doi.org/10.1002/hep.24330

2. Ulvik RJ. The liver in haemochromatosis. J Trace Elem Med Biol 2015 Jul; 31: 219-24. http://dx.doi.org/10.1016/j.jtemb.2014.08.005

3. Feder JN, Gnirke A, Thomas W, Tsuchihashi Z, Ruddy DA, Basava A. et al. A novel MHC class I-like gene is mutated in patients with hereditary haemochromatosis. Nat Genet 1996 Aug; 13(4): 399-408. http://dx.doi.org/10.1038/ng0896-399

4. Kanwar P, Kowdley KV. Diagnosis and treatment of hereditary hemochromatosis: an update. Expert Rev Gastroenterol Hepatol 2013 Aug; 7(6): 517-30. 
http://dx.doi.org/10.1586/17474124.2013.816114

5. Santos PC, Krieger JE, Pereira AC. Molecular diagnostic and pathogenesis of hereditary hemochromatosis. Int J Mol Sci 2012; 13(2): 1497-511. http://dx.doi.org/10.3390/ijms13021497

6. Deugnier Y, Turlin B. Pathology of hepatic iron overload. World J Gastroenterol 2007 Sep 21; 13(35): 4755-60. http://dx.doi.org/10.3748/wjg.v13.i35.4755

7. Kremastinos DT, Farmakis D. Iron overload cardiomyopathy in clinical practice. Circulation 2011 Nov 15; 124(20): 2253-63. http://dx.doi.org/10.1161/CIRCULATIONAHA.111.050773

8. Seckington R, Powell L. HFE-Associated Hereditary Hemochromatosis. GeneReviews ${ }^{\circledR}$ [Internet]. [Cited in 2015 Sep 17]. Available from: http://www.ncbi.nlm.nih.gov/books/ NBK1440/.

9. Zarrilli F, Elce A, Scorza M, Giordano S, Amato F, Castaldo G. An update on laboratory diagnosis of liver inherited diseases. Biomed Res Int. 2013; 2013: 697940. http://dx.doi.org/10.1155/2013/697940

10. Kew MC. Hepatic iron overload and hepatocellular carcinoma. Liver Cancer 2014 Mar; 3(1): 31-40. http://dx.doi.org/10.1159/000343856

11. Vantyghem MC, Dobbelaere D, Mention K, Wemeau JL, Saudubray JM, Douillard C. Endocrine manifestations related to inherited metabolic diseases in adults. Orphanet J Rare Dis 2012 Jan 28; 7:11

http://dx.doi.org/10.1186/1750-1172-7-11

12. Bejar D, Colombo PC, Latif F, Yuzefpolskaya M. Infiltrative Cardiomyopathies. Clin Med Insights Cardiol 2015 Jul 8; 9(Suppl 2): 29-38.

13. Cheng CF, Lian WS. Prooxidant mechanisms in iron overload cardiomyopathy. Biomed Res Int 2013; 2013: 740573.

14. Kondur AK, Li T, Vaitkevicius P, Afonso L. Quantification of myocardial iron overload by cardiovascular magnetic resonance imaging T2* and review of the literature. Clin Cardiol 2009 Jun; 32(6): E55-9.

http://dx.doi.org/10.1002/clc.20310

15. van Vulpen LF, Roosendaal G, van Asbeck BS, Mastbergen SC, Lafeber FP, Schutgens RE. The detrimental effects of iron on the joint: a comparison between haemochromatosis and haemophilia. J Clin Pathol 2015 Aug; 68(8): 592-600. http://dx.doi.org/10.1136/jclinpath-2015-202967

16. Husar-Memmer E, Stadlmayr A, Datz C, Zwerina J. HFE-related hemochromatosis: an update for the rheumatologist. Curr Rheumatol Rep 2014 Jan; 16(1): 393. http://dx.doi.org/10.1007/s11926-013-0393-4

17. Sredoja Tišma V, Bulimbašić S, Jaganjac M, Stjepandić M, Larma M. Progressive pigmented purpuric dermatitis and alopecia areata as unusual skin manifestations in recognizing hereditary hemochromatosis. Acta Dermatovenerol Croat 2012; 20(3): 181-6.

18. Brandhagen DJ, Fairbanks VF, Baldus W. Recognition and ma- nagement of hereditary hemochromatosis. Am Fam Physician 2002 Mar 1; 65(5): 853-60.

19. Wright JA, Richards T, Srai SK. The role of iron in the skin and cutaneous wound healing. Front Pharmacol 2014 Jul 10; 5: 156 .

http://dx.doi.org/10.3389/fphar.2014.00156

20. Falize L, Guillygomarc'h A, Perrin M, Lainé F, Guyader D, Brissot P, et al. Reversibility of hepatic fibrosis in treated genetic hemochromatosis: a study of 36 cases. Hepatology 2006 Aug; 44(2): 472-7.

http://dx.doi.org/10.1002/hep.21260

21. Panella M, Koehler SA, Shakir A, Williams K. Unsuspected hereditary hemochromatosis at forensic autopsy: its presentation, confirmation, and implications. Am J Forensic Med Pathol 2011 Mar; 32(1): 20-4.

http://dx.doi.org/10.1097/PAF.0b013e318187decb

\section{DIAGNOSTICS OF HEMOCHROMATOSIS AND POST - MORTEM AUTOPSY IMPORTANCE: CASE REPORT}

I. Mažeikaitė, D. Banionis, S. Laima, A. Jasulaitis

Key words: iron overload, iron storage disease, sudden death, autopsy.

Summary

Hemochromatosis (also called iron overload or iron storage disease) is the disease which is characterised by organ (especially liver, also, pancreas, heart, joints, bones, hypophysis, skin and nails) lesion because of iron overload in the system. Hereditary hemochromatosis is one of the most common genetic disorder in Caucasians. In the Northern Europe population, 1 of $220-250$ is identified. Primary hemochromatosis is a disease inherited in an autosomal recessive way, usually related to HFE gene. The course of primary hemochromatosis till midlife (40-60 years) is asymptomatic. The triad is characteristic to hemochromatosis: liver cirrhosis, diabetes and skin hyperpigmentation. Lesion of cardiomyocytes arouses heart deficiency and can cause sudden death. Usually, the disorder is diagnosed accidentally - after diagnosing the enlarged iron concentration in blood serum and after the emergence of severe, sometimes deadly complications. Having the hereditary hemochromatosis, enlarged serum ferritin and transferrin saturation are diagnosed. Hereditary hemochromatosis can be diagnosed by genetic examination - finding of HFE gene and C282Y, H63D mutations. The main principle of hemochromatosis treatment is reducing the toxic effect of iron. Treatment of primary hemochromatosis is flebotomy (removing blood). Those patients, for whom flebotomy is counter-indicated or who do not tolerate this method of treatment, have medication treatment applied - with chelates, liver transplantation is rarely performed. This article presents the analysis of the clinical case of the patient, who had sudden death and final diagnosis was determined only after performing autopsic investigation, and the review of hemochromatosis epidemiology, etiology, clinical symptoms, the newest recommendations for diagnostics and treatment.

Correspondece to: mazeikaite.ieva.vumf@gmail.com

Gauta 2016-02-21 